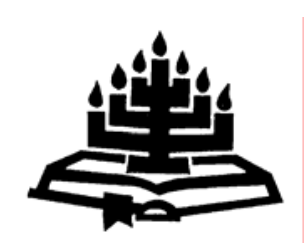

\title{
Onderweg na 'n Christelike samelewings- beskouing: Bybelse grondslae en historiese ontwikkeling
}

\author{
B.J. van der Walt \\ Skool vir Filosofie \\ Potchefstroomkampus \\ Noordwes-Universiteit \\ POTCHEFSTROOM \\ E-pos: hannah@intekom.co.za
}

\begin{abstract}
Towards a Christian perspective on social life: Biblical foundations and historical development

This article is structured in the following way: The introduction asks the practical question why Christianity has such a small impact on contemporary society. This topical question is partly answered by indicating that most Christians lack a worldviewish framework or social philosophy to inspire them to get involved outside their churches and do so correctly. In the second section a brief explanation of the possible solutions to this problem indicates that the reformational social philosophy may offer some help. Christian theology and Christian philosophy should mutually assist each other in this important endeavour to shape a Christian worldview, including a perspective on social life. The third section indicates how such a philosophy for social life can be firmly based on God's Word. In light of the fact that this social philosphy is not well-known, the last part of the article provides a brief historical survey of how this kind of societal philosophy originated and developed over the course of more than a century.
\end{abstract}

\section{Opsomming}

Onderweg na 'n Christelike samelewingsbeskouing: Bybelse grondslae en historiese ontwikkeling

Hierdie artikel is soos volg saamgestel: Die inleiding stel die praktiese vraag waarom Christene so min invloed op die huidige samelewing uitoefen. 'n Gedeeltelike antwoord op hierdie aktuele vraag is dat weinig Christene oor 'n denkraamwerk of 
samelewingsbeskouing beskik wat hulle kan inspireer om betrokke te raak en dit op die regte manier te doen. In die tweede afdeling blyk uit 'n vlugtige verkenning van die moontlike oplossings vir hierdie leemte, dat 'n reformatoriese samelewingsfilosofie van hulp kan wees. Die Christelike teologie en Christelike filosofie behoort in die uitbou van hierdie belangrike saak van 'n Christelike lewensvisie en perspektief op die samelewing mekaar wedersyds te ondersteun. Die bedoeling met die derde afdeling is om aan te toon dat so 'n samelewingsvisie stewig in God se Woord begrond kan word. Die laaste gedeelte bied in die lig van die onbekendheid van hierdie samelewingsbeskouing by baie mense 'n kort historiese oorsig oor die ontstaan en ontwikkeling daarvan oor 'n tydperk van meer as 'n eeu.

\section{Die vraagstuk}

\section{1 'n Aktuele probleem}

Die probleem van die verhouding tussen Christendom en kultuur is so oud soos die Christendom self. Die finale woord daaroor is nog steeds nie gespreek nie, sodat dit nog steeds 'n aktuele probleem bly. 'n Onderdeel van hierdie breëre vraagstuk is die vraag hoe Christene en kerke die breë samelewing (die sosiale lewe, politiek, ekonomie, ensovoorts) moet beskou en hoe so 'n lewensbeskoulike visie hulle moet lei om werklik op alle terreine buite die kerk op 'n praktiese wyse betrokke te wees. 'n Antwoord hierop kan 'n bydrae lewer om die konkrete probleem van die geringe invloed van Christene en kerke op die samelewing te help oplos.

Ongelukkig is dit 'n feit dat die meeste kerke, Christene en teoloë oor geen of slegs 'n baie onduidelike samelewingsbeskouing beskik - 'n stelling wat deur talle uitsprake gestaaf word. Slegs enkele persone kan egter in die beperkte ruimte van hierdie artikel aan die woord gestel word.

\subsection{1 'n Valse dualisme}

Met die volgende woorde ontbloot Fowler (1985:1) uit Australië die valse dualisme wat nog steeds by baie Christene voorkom:

It seems very sad that personal piety and social concern are often regarded among Christians as a matter of either/or. Where there is deep concern for personal piety and devotion, all too often there is only the most superficial attention given to the social meaning of the gospel. On the other hand, where there is a deep social concern, all too often the development of 
personal piety is neglected ... The result is a serious onesidedness in the reading of Scripture.

Tereg sê Fowler dan dat 'n Christen volgens die Skrif nie tussen die twee hoef te kies of die twee aktiwiteite dualisties teenoor/langs mekaar hoef te stel nie. Die Skrif leer dat die Here persoonlik en sosiaal, op alle terreine, gehoorsaam en gedien moet word.

\subsubsection{Die gevolge van dualisme}

Adeyemo (1993:4) toon die konsekwensies van so 'n dualisme in die praktyk aan:

For decades in Africa, evangelism and missionary activities have been directed at getting people saved (i.e. spirituallly) but losing their minds. Consequently we have a continent south of the Sahara that boasts of an over $50 \%$ Christian population on the avarage, but with little or no impact on society.

Van der Walt (2002:259) stem saam dat die meeste Christene in Afrika in twee wêrelde leef: 'n "geestelike" (waar Christus se gebooie geld) en 'n "wêreldse" (waar ons self ons weg moet soek).

Daarna wys hy op die lewensbeskoulike implikasie daarvan:

Therefore most Christians strongly believe that the Gospel provides spiritual clothing and footwear, but when it comes to socio-political clothes and shoes, the Gospel cannot provide. Because we cannot go naked and barefoot in public, Christians then buy socio-economic-political clothing at the secular market ... and walk in the clothes and shoes that do not really fit them as Christians. (Van der Walt, 2002:259).

\subsection{3 'n Simptomatiese benadering is nie voldoende nie}

Gekonfronteer met allerlei samelewingsprobleme soos armoede, misdaad, geweld en korrupsie, is baie Christene geneig om slegs "noodhulp" toe te pas. Daarom herinner McCarthy et al. (1981:13) uit die VSA: "The crisis is one of structure and design. It concerns the way various institutions in society are organized and function." Die oplossing vir die samelewingsprobleme lê dus ook dieper: "The time is ripe for the consideration of a new paradigm, a new way of looking at persistent problems, seeking a renewal by means of structural change." (McCarthy et al., 1981:13).

Hierdie behoefte word ook bevestig uit Korea. Son (1999:180 e.v.) vestig ook eers die aandag op die dualistiese denkwyse onder 
Christene in sy land. Prediking, kerkplanting en teologiese opleiding later was nie net die primêre nie, maar selfs die enigste doel van Christene, terwyl hulle van 'n integrale Christelike lewe in die samelewing vergeet het. Geloof en lewe is dus as twee afsonderlike terreine beskou. Hy roep dus die kerke op tot ernstige herbesinning. Deur die klem alleen op die verhouding tot God te lê, terwyl Christene se sosiale verantwoordelikheid verwaarloos word, beteken dat hulle hul unieke relevansie vir die samelewing verloor.

Sy oplossing stem ooreen met dié van McCarthy et al. (1981). Wat Christene nodig het indien hulle nie ad hoc, sonder enige riglyne betrokke wil raak nie, is "an effective theoretical support for their social actions" (Son, 1999:186) - met ander woorde, 'n duidelike, rigtinggewende samelewingsbeskouing.

Die voorafgaande impliseer nie dat 'n gebrek aan 'n Christelike lewens- en samelewingsvisie of selfs 'n Christelike filosofie (wetenskaplike besinning op 'n mens se lewensvisie) die enigste oorsaak is vir die geringe impak van die meeste Christene op die samelewing nie. 'n Legio ander faktore sou opgenoem kon word. Wat wel gesuggereer word, is dat die lewensbeskoulik-filosofiese leemte 'n belangrike bydraende rede kan wees en gevolglik hier verder ondersoek behoort te word.

\section{Op soek na moontlike oplossings}

In die loop van die geskiedenis (vgl. Niebuhr, 1951; Wolters, 1990) het die volgende vyf basiese houdings van die Christendom telkens na vore gekom: die Christen teen die kultuur; die Christen gelyk aan die kultuur; die Christelike geloof vervolmaak die kultuur; die Christen beklee 'n posisie langs die kultuur en die Christen moet die kultuur transformeer of vernuwe. Dieselfde standpunt geld ook ten opsigte van die meer spesifieke probleem van hoe Christene die samelewing teoreties beskou en prakties daarin betrokke is.

\subsection{Vier onaanvaarbare visies}

Indien, volgens die eerste visie, die Christen hom prinsipieel van die samelewing distansieer, bestaan daar nie 'n behoefte aan 'n samelewingsbeskouing nie. Wanneer daar, volgens die tweede standpunt, nie 'n wesenlike verskil tussen die Christelike lewe en die omringende kultuur bestaan nie, is 'n eie, Christelike samelewingsvisie ook oorbodig. 
Die derde beskouing, die Christen vervolmaak die kultuur, is die klassieke Rooms-Katolieke visie wat 'n verkerkliking van die samelewing inhou. Hiervolgens word die Christelike geloof tot die kerk beperk - die breëre Bybelse perspektief van God se allesomvattende koninkryk ontbreek. Kerk en koninkryk word vereenselwig. Die samelewing (politiek, ekonomie, ensovoorts) kan alleen Christelik wees wanneer dit kerklik "gestempel" of "gedoop" (vervolmaak) is. Op wetenskaplike gebied beteken dit dat die teologie se veld so breed word dat dit vir feitlik alles Christelike oplossings moet bied.

Hierdie vertrekpunte word in die Roomse samelewingsfilosofie die beginsel van subsidiariteit genoem. (Vir volledige uiteensettings asook reformatoriese kommentaar op hierdie samelewingsbeskouing, vgl. Sadowsky, 1986; Skillen \& McCarthy, 1991:137-228, 275-277, 377-396, 398-400; Chaplin, 1994:81-100.)

Ook die vierde visie, die Christen langs die samelewing, bied nie 'n antwoord nie, omdat ook dit inherent dualisties is. Dit beteken nie dat daar nie kritiek op die samelewing gelewer word nie, maar dit is meestal oppervlakkig en gegrond op losstaande Skrifgedeeltes in plaas van op 'n omvattende, samehangende visie - 'n dieper analise van die samelewingstrukture ontbreek.

\subsection{Transformasie as 'n oplossing}

Die vyfde standpunt, dié van vernuwing of transformasie van die kultuur en samelewing, bied egter moontlikhede. Wolterstorff (1983: 43) tipeer hierdie standpunt as "world-formative Christianity" en hy reken tot hierdie groep die Bevrydingsteologieë en die Reformatoriese (Calvinistiese) filosofie se samelewingsbeskouings.

\subsubsection{Bevrydingsteologieë}

Die verskillende bevrydingsteologieë wat gedurende die laaste kwart van die vorige eeu populêr was, is inderdaad 'n voorbeeld van 'n dieper Christelike analise van die samelewing (vgl. Wolterstorff, 1983:42-53 vir 'n kort oorsig). Dié beweging het intussen egter grootliks van die toneel verdwyn.

Skillen en McCarthy (1991:115-136 en 369 e.v.) analiseer die samelewingsvisie van die bevrydingsteologie in detail. Teenoor die onregverdige, onderdrukkende verlede en hede doen hierdie teoloë ' $n$ beroep op 'n toekoms van vryheid. Wat verwerp word (die onreg van die verlede en hede) is duidelik, maar hulle prinsipieel-teoretiese riglyne vir 'n toekomstige, beter samelewing is egter onduidelik (Skillen 
\& McCarthy, 1991:373). Omdat bevrydingsteoloë van die (neo-) Marxisme in hulle sosiale analise gebruik maak (vgl. Wolters, 1991:229 e.v.), is die vraag ook of so 'n samelewingsbeskouing werklik as integraal-Christelik beskou kan word. Spykman et al. (1988:232) het die situasie in Latyns-Amerika persoonlik ondersoek en hulle het groot waardering vir belangrike Bybelse motiewe wat die bevrydingsteoloë weer na vore bring. Maar ook hulle stel die vraag of die bevrydingsteologie losgemaak kan word van die materialistiese beginsels van die Marxisme. Wetenskaplike metodes is tog nie iets neutraals nie. Dit laat selfs die volgende vraag ontstaan: Indien die Marxisme aangehang word om 'n samelewing van die individualistiese kapitalisme te bevry, is daar dan enige waarborg dat dit nie in kollektivistiese onderdrukking kan verval nie?

\subsection{2 'n Reformatoriese samelewingsfilosofie}

Volgens Wolterstorff (1983:43) is die tweede soort wêreldtransformerende Christelike geloof dié van die neo-Calvinisme. Dit bevat "a penetrating analysis of our contemporary social world combined with a comprehensive Christian vision of society". Dit wil dus lyk asof hierdie visie, wat die slytasie van die geskiedenis oorleef het, die moeite werd is om verder te ondersoek.

\subsection{Twee uitdagings}

Om so ' $n$ verkenning egter oortuigend te maak, moet die volgende twee samehangende struikelblokke uit die weg geruim word: duidelikheid moet verkry word oor die verhouding tussen teologie en filosofie, en ook oor die Bybelse grondslae van 'n reformatoriese samelewingsfilosofie.

\subsubsection{Die verhouding tussen teologie en filosofie}

Baie Christelike teoloë staan, dikwels tereg, skepties teenoor die filosofie, omdat die meeste filosofieë sekulêr van aard is. Ongelukkig het dit daartoe gelei dat ook die Reformatoriese filosofie en samelewingsfilosofie by baie Christene en Christelike teoloë, ook in SuidAfrika, onbekend gebly het.

Christelike teoloë en Christelike filosowe behoort egter op hierdie terrein nóu saam te werk.

Een Christlijke filosofie (kan) niet om een blijvende Bijbels- en systematisch-theologische bezinning heen ... Zoals omgekeerd een Bjbels- en zeker een systematisch-theoloische bezinning 
nooit om wijsgerige kennis en doordenking heen kan (Van den Brink et al., 1997:41.)

Elders: "De theologie heeft bij haar antithetische discussies de filosofie broodnodig, vooral de analyses die deze aanrijk, en waar de Wijsbegeerte der Wetsidee zo sterk in is." (Van den Brink et al., 1997:107.)

Die punt waarop hierdie onderlinge samewerking kan toespits, is op die uitbou van 'n Christelike lewensbeskouing:

We hebben elkaar hard nodig in de bezinning op een Christelijke wereldbeskouing die adequaat, authentiek en overtuigend in kan gaan op de intellektuele eisen en uitdagingen van onze tijd. (Van den Brink et al., 1997:44.)

Hierdie oproep vanuit Nederland word ondersteun deur Adeyemo, wat (vgl. hierbo) gekla het oor die weinig invloed wat Christene in Afrika op hulle samelewings uitoefen. Ook hy sien lig in toerusting met 'n Christelike lewensvisie, met as belangrike onderdeel 'n Christelike samelewingsfilosofie:

We are convinced that an integrated Christian worldview based upon the Holy Scriptures, the Bible, is an indispensable foundation to live out an authentic Christian life in our contemporary society, hence the imperative of calling all Christians to develop a Christian worldview within the African context. The battle therefore, is for the Christian mind, to think Christianly and to grasp the full implications of the Lordship of Christ over all areas of life. This implies the necessity to develop a Christian anthropology and Christian social philosophy. (Adeyemo, 1993:227.)

\subsubsection{Die Bybelse begronding}

Die twyfel by sommige teoloë oor die bruikbaarheid van filosofiese insigte in hulle vakgebied kan dikwels daaraan toegeskryf word dat die betrokke samelewingsfilosofie nie, of nie duidelik genoeg op die Woord van God gegrond is nie. Hoewel 'n reformatoriese samelewingsfilosofie nie net op Bybeltekste gebou kan word nie (sien later waarom), hoef oor sy eksplisiete Christelike karakter geen kommer te bestaan nie. Nogtans word in hierdie artikel ook aan die Bybelse grondslae aandag gegee. 


\section{Die Bybelse begronding van 'n Christelik-reforma- toriese samelewingsbeskouing}

Ter inleiding eers 'n baie kort tipering (Spykman, 1976:164-169 bied 'n uitstekende samevatting) van 'n reformatoriese samelewingsvisie voordat verduidelik word hoe hierdie idee op God se Woord gegrond is.

\subsection{In 'n neutedop gestel}

Die pluralistiese samelewingsvisie, wat duidelik te onderskei is van sowel individualisme as kollektivisme, gaan uit van die Bybelse gedagte van die absolute soewereiniteit van God oor alles en alle menslike lewensterreine. Kuyper (vgl. Kuyper, 1998:488) se bekende uitspraak lui: "... there is not a square inch in the whole domain of our human existence over which Christ, who is sovereign over all does not cry: 'Mine!'”.

God handhaaf sy soewereiniteit deur konstante skeppingsordeninge of struktuurwette. Hiervolgens het elke samelewingsverband 'n godgegewe, eiesoortige identiteit, gesagstruktuur en roeping of arbeidsveld wat verskil van dié van alle ander verbande. In ooreenstemming met hierdie beginsel van soewereiniteit in eie kring (of ' $n$ verskeidenheid verantwoordelikhede), mag die een verband dus nie 'n ander se taak oorneem of daaroor heers nie. Gesagsdraers in die verskillende lewensverbande se amp, gesag, mag en verantwoordelikheid is gekwalifiseerd en dus beperk. Terselfdertyd bestaan die verskillende verbande nie geïsoleerd van mekaar nie, maar moet saamwerk in diens aan die omvattende koninkryk van God.

In sy bekende toespraak oor soewereiniteit in eie kring by die opening van die Vrije Universiteit in 1880, verduidelik Kuyper (vgl. Kuyper, 1998:467, 468) hierdie gedagte met 'n beeld. In 'n horlosie het elke rat sy eie plek en draai om sy eie as (die verskillende samelewingsverbande). Indien 'n rat egter vashaak of uit sy plek losraak, kan die horlosie nie werk nie. Maar die horlosie (die hele samelewing) kan ook nie funksioneer indien die nodige interaksie tussen die verskillende ratte ontbreek nie.

Hierdie beeld toon duidelik dat die beginsel van soewereiniteit in eie kring nie net 'n negatiewe doel het, naamlik om te verhoed dat ' $n$ samelewingsverband sy eie taak verwaarloos of in 'n ander verband se terrein inmeng nie. Dit wil die positiewe doel bereik dat elke verband sy eie roeping sal nakom en die samelewing as geheel daardeur floreer (vgl. Dengerink, 1961:211). 
Omdat God se skeppingsordeninge vir die samelewing soms verkeerd verstaan word, is dit ook belangrik om te beklemtoon dat hulle nie staties is nie, maar dinamiese beginsels of kragte is waardeur God die lewe lei. Hierdie skeppingsorde moet dan voortdurend in die geskiedenis gerealiseer (gepositiveer) word. Tereg beklemtoon Dengerink (1961:211) dat die konkrete taak van 'n gesin, kerk of staat nie vir eens en altyd omskryf kan word nie, aangesien omstandighede dit kan laat verskil. Daar moet dus skerp onderskei word tussen die aard (deur God se skeppingsorde bepaal) en die konkrete taak (volgens menslike positivering) in spesifieke omstandighede. Die eerste is konstant terwyl die tweede voortdurend wissel.

Saam met hierdie strukturele pluralisme beklemtoon die reformatoriese visie ook konfessionele (religieuse) pluralisme. Dit beteken dat verskillende godsdienstige groepe die reg behoort te hê om in organisasies, soos 'n Christelike politieke party, en instellings, soos 'n Moslemskool, strukturele gestalte te gee aan hulle eie diepste oortuigings.

\subsection{Skeppings- en Woordopenbaring}

Voordat nagegaan word wat die Bybel as boustene vir 'n samelewingsfilosofie bied, is dit noodsaaklik dat die reformatoriese visie op God se openbaring eers verduidelik word. Dit is gewens, omdat daar veral twee redes is waarom sommige Christene nie 'n Bybelsbegronde samelewingsfilosofie kan ontwikkel nie (vgl. punte 1 en 2 hierbo). Die eerste is omdat hulle die Skrif privatiseer en die tweede omdat hulle die Bybel monopoliseer. Hier sal verduidelik word waarom hierdie visies albei onaanvaarbaar is. Terselfdertyd sal die eie visie op die Skrif, wat wel die deur na 'n samelewingsbeskouing oopmaak, verduidelik word.

\subsubsection{Te min van die Skrif verwag}

Die eerste groep Christene wat die Skrif privatiseer, is van mening dat God se Woord slegs betekenis het vir die persoonlike en kerklike lewe en nie vir die openbare lewe (breë samelewing) nie. Volgens die reformatoriese tradisie word hierdeur egter te min van die Bybel verwag.

Die mens se hele lewe is religieus-bepaald; dit is 'n omvattende antwoord (in gehoorsaamheid of ongehoorsaamheid) aan God se openbaring. As religieuse boek maak die Skrif 'n appèl op ons hele lewe. Die vraag is dus nie of nie, maar hoe die Skrif lig bied op die sosiale lewe. 
As voorwetenskaplike boek mag dit nie as 'n wetenskaplike handboek vir die ontwerp van sosiale teorieë gebruik word nie. Dan word weer te veel van die Skrif verwag. Die Bybel praat wel oor politiek (bv. in Rom. 13:1-7), maar nie op politokologiese wyse nie; oor die huwelik (bv. Ef. 5:22-32), maar nie in sielkundige terme nie; oor die opvoeding van kinders (bv. Ef. 6:4), maar anders as 'n opvoedkundige; oor sosiale vraagstukke (bv. Ef. 6:5-9), maar nie in sosiologiese taal nie. Gewoonlik beklemtoon die Skrif in al hierdie menslike verhoudings die sentrale gebod van liefde tot die naaste.

In die Skrif gee God dus nie volledige voorskrifte vir die samelewing nie. Die rede is dat Hy sy wil ook in die skepping openbaar en Christene die skepping self (gesin, staat, bedryf, ensovoorts) moet bestudeer om die wetmatigheid daarin op te spoor, sodat hulle reg kan opvoed, regeer, sake doen en so meer.

Die tweede struikelblok is:

\subsubsection{Te veel van die Skrif verwag}

Die tweede rede waarom 'n samelewingsfilosofie by baie Christene ontbreek, is omdat hulle die Skrif monopoliseer en dus alles alleen vanuit die Bybel wil aflei. Ook die riglyne vir die samelewing moet regstreeks (dikwels deur middel van 'n fragmentariese beroep op losstaande tekste) uit die Bybel afkomstig wees. Op só 'n wyse word die Skrif egter óórvra, te veel daarvan verwag en in Biblisisme verval (vgl. McCarthy et al., 1981:152).

Die Reformatoriese tradisie beklemtoon dus dat die Skrif nie God se eerste en enigste openbaring is nie, maar die tweede. Lank voordat sy Woord op skrif gestel was, het hy Homself alreeds in en deur sy skepping openbaar. In hierdie openbaring gaan dit veral oor sy wil vir die skepping. (Vgl. byvoorbeeld Ps. 19:8-10 wat van God se woordelose, nie-talige openbaring praat as sy bevele, gebooie, eise en bepalings.) Die skeppingswoord van God laat dinge dus nie net ontstaan nie, maar hou hulle in stand en bestuur hulle volgens sy wil.

Die mens as religieuse wese antwoord op hierdie skeppingswoord in gehoorsaamheid of ongehoorsaamheid. Anders as in die geval van die Skrifopenbaring, spreek God se skeppingsopenbaring tot gelowiges én ongelowiges. Elke mens kan byvoorbeeld daaruit leer dat God se wil vir die huwelik wedersydse getrouheid is en vir die staat geregtigheid vir almal. 
Die gevolgtrekking is dat die samelewing met sy verskillende geledinge nie sommer vanself funksioneer of bloot die skepping van outonome mense is nie. Dit is afhanklik van God en gebonde aan sy skeppingsordeninge.

McCarthy et al. (1981:151) stel dit soos volg:

There is a constancy to the creation order that holds for the social order. The life of a community cannot unfold arbitrarily or capriciously. The structural options open to mankind in ordering society are not infinite; the boundaries are circumscribed, and a community gives shape and form to its social order within them.

Ongelukkig het dit in die verlede gebeur dat God se skeppingsordeninge verkeerd verstaan is en selfs misbruik is soos ter regverdiging van apartheid. So 'n verkeerde gebruik het selfs daartoe aanleiding gegee dat sommige Christendenkers begin twyfel het of daar so iets soos God se riglyne vir die sosiale lewe bestaan en daarom het hulle in sekularisme en relativisme verval. Dit is verkeerd om ons gebrekkige begrip daarvan met God se verordeninge te vereenselwig. Dit is egter ook verkeerd om die noue verband tussen die twee te ontken.

\subsubsection{Die korrekte visie}

Twee uiterstes is duidelik: om té veel van die Skrif te verwag lei tot Biblisisme. Maar om met God se skeppingsopenbaring te volstaan, kan tot sekularisme lei. Wat is dan die verhouding tussen sy tweërlei openbaring?

$\mathrm{Na}$ die sondeval het die mens doof en blind geword vir God se skeppingsopenbaring, sodat dit nie meer voldoende is nie. Dit is nie God se openbaring wat gefaal het nie, maar die mens se antwoord daarop - die mens onderdruk en vervang dit (Rom. 1:18, 23). In sy oneindige genade "herpubliseer" God in 'n talige vorm egter sy openbaring.

Scripture was given as a corrective, reinforcing the original revelation upon our minds, redirecting our attention to the meaning of it all, refocussing its intent and purpose (McCarthy et al., 1981:152).

Elders stel dieselfde skrywers dit só:

Scripture is a representation of God's will, representing his new initiative calling the social order back to its intended design ... The Bible is the second revised edition of God's Word, but it is 
still at heart the same Word. God's will for life in this world is constant. (McCarthy, 1981:153.)

Omdat die strukturele norme van die samelewing as gevolg van die mens se sondigheid nie meer beantwoord aan God se wil vir die samelewing nie, wil God se Skrifopenbaring dus die mens se verkeerde antwoorde op sy skeppingsopenbaring regstel.

Om duidelik te maak hoe versigtig 'n mens God se Skrifopenbaring moet bestudeer, nog die volgende opmerking. In die skeppingsopenbaring ontdek 'n mens die "objektiewe" of konstante wil van God. Sy Skrifopenbaring gee die "subjektiewe" kant, dit wil sê hoe mense, reg of verkeerd, op sy skeppingsordeninge gereageer het. Hierdie menslike antwoorde vind verder plaas in 'n bepaalde tyd, omstandighede en kultuur. Wat in die Skrif staan, kan dus nie onveranderd net so op die samelewing van vandag toegepas word nie - dit is Biblisisme. In die lig van die vorme van destyds, soos dit in die Skrif na vore kom, moet die norme vir vandag afgelei word dit wil sê God se oorspronklike skeppingsordeninge. In die formulering van sulke eietydse norme vir die samelewing moet God se liefdesgebod gestalte kry vir 'n spesifieke samelewingsverband in spesifieke omstandighede.

Ten slotte moet erken word dat ook van die reformatoriese samelewingsbeskouing geld dat dit 'n subjektiewe, kultuur- en tydsbepaalde antwoord is op God se objektiewe skeppingsopenbaring in die lig van sy Skrifopenbaring onder leiding van sy Gees. Terselfdertyd is die skrywer van mening dat hierdie soort samelewingsvisie ' $n$ ernstige poging is om aan die godgegewe norme vir die samelewing reg te laat geskied.

\subsection{Belangrike Bybelse perspektiewe as boustene vir 'n samelewingsbeskouing}

Noudat aangetoon is dat die Skrif nie God se enigste openbaring is nie, asook hoe sy tweërlei openbaring 'n eenheid vorm, kan teruggekeer word na die vraag wat reeds vroeër gestel is, naamlik of die Bybel enige lig op die samelewing kan werp.

Met die drie Bybelse perspektiewe wat volg, is die boodskap van die Skrif vir die menslike samelewing uiteraard nie uitgeput nie. Hulle dien slegs as voorbeelde van hoe dit moontlik is om, sonder om na "teksbewyse" te soek, breë Bybelse perspektiewe vir die uitbou van 'n eie samelewingsvisie te kan gebruik. 


\subsubsection{Geleidelike strukturele differensiasie}

Aan die begin van die skepping was daar nie net konfessionele eenheid nie (Adam en Eva het God alléén gehoorsaam), maar ook strukturele eenheid ('n ongedifferensieerde samelewing). Die hele samelewing was in die uitgebreide familie gesentreer.

Volgens God se kultuurmandaat (Gen. 1:28 en 2:15) ontvang die mens egter die roeping om die skeppingspotensiaal te ontwikkel en die rykdom daarin te laat ontplooi. Alreeds by Adam en Eva is daar 'n geleidelike groterwordende verskeidenheid van roepings: die huwelik- en gesinslewe, om die aarde te bewerk (landbou), die tuin op te pas (regering), die diere te benoem (die opdrag om kennis te verkry) en saam met God in die tuin te wandel (die godsdienstige roeping). Elke taak is iets eiesoortigs en nie tot 'n ander herleibaar nie. Die lewe in en na die paradys wat dus alreeds een wat deur God georden is.

Ná Adam en Eva tree nog verdere diversifikasie in. Kain word 'n landbouer en Abel 'n veeboer, Nimrod 'n jagter, Jabal nog 'n veeboer, Jubal iemand wat die estetiese (musiek) ontwikkel en TubalKain 'n smid/metaalwerker. Ook uit die geskiedenis van Moses blyk dit dat een mens nie alle ampte kan beklee nie - sy skoonvader adviseer hom om sekere take te delegeer.

In die Ou Testament word die drie ampte van profeet, priester en koning, wat aanvanklik in een persoon gesetel is, geleidelik ook duideliker onderskei. Koning Saul en Ussa word byvoorbeeld streng deur God gestraf omdat hulle priesterlike werk verrig het. Dit blyk ook in die geval van koning Dawid wat deur die profeet Natan tereggewys word ten tye van die priesterskap van Abjatar.

Ook in die Nuwe Testament ontwikkel verskillende kerklike ampte soos diaken, ouderling en prediker uit die oorspronklike dissipel- en apostelampte. Daar is ook sprake van owerhede en onderdane, mans en vroue, ouers en kinders.

Die Bybel vertel dus hoe mense aan God se norme vir die samelewing, soos in sy skeppingsopenbaring gegee, in die loop van die geskiedenis gestalte gegee het in die verskillende samelewingstrukture. Hoewel hierdie historiese ontwikkeling nie vir alle tye normatief mag wees nie, reflekteer dit tog 'n pluralistiese samelewing as ideaal, gelei deur die beginsel van soewereiniteit in eie kring. 
Dit is belangrik om die menslike verantwoordelikheid in die totstandkoming van die verskeidenheid verbande te erken. God stig nie die eerste kerk nie, maar skep die mens as 'n godsdienstige wese om dit self te kan doen. Insgelyks het Hy die mens met 'n politieke aanleg, ' $n$ besef van die noodsaak van publieke geregtigheid, geskep, sodat die mens later verskillende regeringsvorms tot stand gebring het. Skole is alleen moontlik omdat God die mens ' $n$ opvoedende en lerende wese gemaak het en ook sekere norme daarvoor neergelê het.

\subsubsection{Gedifferensieerde liefde}

God se gebod van liefde tot die naaste is nie iets algemeens of vaags nie, want dit moet spesifiek en konkreet in verskillende menslike verhoudings uitgeleef word. Hierdie konkretisering of positivering hang dus af van die verskeidenheid lewensgebiede (vgl. Van der Walt, 2002:264, 265). In die huwelik kry liefde die gestalte van wedersydse trou; in die gesin kom dit na vore as ouer- en kinderliefde; op politieke terrein as geregtigheid; op ekonomiese gebied as sorgvuldige rentmeesterskap; as gesondheidsorg op mediese gebied en op akademiese gebied as noukeurige, sistematiese denke 'n liefde vir jou vakgebied.

Al die soorte liefde is uniek, eiesoortig. Die een is ook nie belangriker as die ander nie. Almal is nodig vir 'n gesonde samelewing. Só 'n samelewing is dus ook volgens hierdie Bybelse perspektief 'n gedifferensieerde samelewing.

\subsubsection{Konfessionele pluralisme Skriftuurlik begrond}

Die vorige twee punte het aangetoon dat strukturele pluralisme 'n korrekte samelewingsvisie is in die lig van die Skrif. Nou word aangetoon dat ook konfessionele pluralisme Skriftuurlik regverdigbaar is.

Volgens die Skrif dien die mens na die sondeval óf die ware God óf iets van die skepping as afgod. Tweedens vertoon die mens die beeld van God of van iets wat in sy plek wat verabsuleer word. In die derde plek skep die mens 'n samelewing volgens sy eie voorstelling van wat menswees beteken. 'n Mens se opvatting oor God/'n godheid, bepaal dus jou visie op die mens (insluitend jouself) en hierdie mensbeskouing is op sy beurt bepalend vir die samelewingsbeskouing wat gehuldig word. Hoe beslissend mensvisies vir samelewingsvisies is, word uitstekend aangetoon in Klapwijk (1995). 
Ook sekulêre denkers soos Stevenson (1974) en Campbell (1987) bring hierdie verband duidelik na vore.

Bogenoemde drie stappe kan ook in omgekeerde volgorde gevolg word. Uit hoe 'n bepaalde samelewing daar uitsien, kan afgelei word hoe mense (wat so 'n samelewing tot gevolg gehad het) hulself beskou en uiteindelik watter soort god hulle dien.

'n Eenvoudige illustrasie is byvoorbeeld wanneer Mammon gedien word, die mens 'n geldgierige materialis word vir wie dit in die samelewingsvorme wat hy skep (bv. op ekonomiese terrein) ten alle koste om welvaart gaan. Die hedendaagse kapitalistiese verkommersialisering van die hele samelewing is ' $n$ duidelike voorbeeld hiervan.

Hierdie perspektief maak duidelik dat die strukture (samelewingsverbande) nie van die religieuse rigting van 'n samelewing geskei kan word nie - die rigting beïnvloed die struktuur. Dit is onmoontlik om soos sekulêre regerings tans probeer doen, godsdienstige oortuigings (sg. private sake) uit die openbare lewe (die sg. publieke terrein) te ban. ' $n$ Beter oplossing is om aan hulle 'n regmatige plek te gun in byvoorbeeld Christelike, Joodse en Moslemskole. Die reformatoriese beginsel van konfessionele pluralisme wil hieraan reg laat geskied.

\subsection{Terugblik}

Tot sover is die probleem van die gebrek aan 'n Christelike samelewingsfilosofie by baie Christene gestel, die reformatoriese samelewingsbeskouing is as kandidaat aanbeveel en daar is aangetoon hoe dit Skriftuurlik begrond is. Wat nog ontbreek, is 'n kort historiese oorsig om duidelik te maak waar hierdie samelewingsbeskouing vandaan kom asook watter denkers dit verder help ontwikkel het.

\section{4. 'n Kort historiese oorsig van die ontstaan en ontwikke- ling van 'n reformatoriese samelewingsfilosofie}

Hoewel die gedagte ver teruggaan, het dit vier eeue geneem voordat die reformatoriese samelewingsbeskouing volwassenheid bereik het. Elkeen van die denkers in hierdie lang geskiedenis het nie alleen op hulle voorgangers voortgebou nie, maar ook die basiese gedagte 'n stappie verder ontwikkel. (Spykman, 1976:170 e.v. behandel onder andere die volgende figure: Calvyn, Athusius, Groen van Prinsterer, Kuyper, Bavinck, Dooyeweerd, Vollenhoven, Van 
Riessen, Veenhof, Vos, Bouma en Meeter.) Daar was sekere sleutelfigure in hierdie proses van ontwikkeling.

\subsection{Johannes Calvyn (1509-1564)}

'n Vollediger oorsig van die verskillende fasette van Calvyn se samelewingsbeskouing is te vinde in Spykman (1976:185-208). Slegs enkele belangrike aspekte word hier genoem.

Die gangbare visie op die samelewing in Calvyn se tyd was die Konstantyns-Thomistiese (Middeleeuse). Volgens die skema van natuur en genade is die samelewing in twee terreine, naamlik staat en kerk verdeel, terwyl die ander verbande óf tot die sekulêre (staat), óf tot die religieuse terrein (kerk) gereken is.

In beginsel breek Calvyn met hierdie Middeleeuse visie. Omdat hy uitgaan van die soewereiniteit van God oor alles, leer hy dat God se Woord nie minder normatief is vir die sogenaamde sekulêre terrein as vir die kerk nie. Sowel staat as kerk is deur God verordineer en moet sy wil vir hulle eie gebied gehoorsaam. Ook die verbande wat as onderdele van staat of kerk beskou is, is terreine waarop Christene hulle godddelike roeping moet vervul (vgl. McCarthy et al., 1981:42-43).

Calvyn kritiseer daarom die staatsabsolutisme van konings wat volgens hom hulself te veel gesag en mag toeëien. Terselfdertyd verwerp hy kerklike heerskappy oor die hele lewe. By die stigting van die Akademie van Genève ag hy dit gevolglik nie noodsaaklik om die toestemming van óf pous óf keiser daarvoor te verkry nie.

Hoewel Calvyn prinsipieel met die gangbare samelewingsvisie gebreek het, het hy dit egter nie tot sy volle konsekwensies deurgevoer nie. Dit blyk byvoorbeeld daaruit dat hy nog steeds begrippe soos "twee ryke", "twee jurisdiksies", ensovoorts gebruik.

Spykman (1976:207-208) se gevolgtrekking ten opsigte van Calvyn lui soos volg:

We find in Calvin a decisive departure from earlier Constantinian-medieval views of society, based upon the nature-grace dichotomy, and structured along the lines of the principle of sphere-subsidiarity with church and state alternatingly pressing their sovereign claims on other institutions in society ... Calvin gave us a breakaway from the Scholastic principle of spheresubsidiarity toward the Reformed principle of sphere-sovereign- 
ity. All that remained was to develop a more consistent followthrough.

McCarthy et al. (1981:42) se konklusie is: "The direction of Calvin's thinking is clear, however, pointing towards structural pluralism." Soos by die meeste van sy tydgenote was daar ongelukkig nog nie van konfessionele pluralisme in sy denke sprake nie (vgl. die geval Servet).

Die Presbiteriaanse vorm van kerkregering (die gelykheid van ampte) het sy oorsprong by Calvyn. Die basiese beginsels wat daaraan ten grondslag gelê het sou eers deur Calvyn se opvolgers ook op die samelewingsverbande buite die kerk van toepassing gemaak word. Een van die belangrikstes was Athusius.

\subsection{Johannes Athusius (1557-1638)}

Met sy hoofwerk Politica methodica digesta (1614) blyk dit dat ook Athusius (1964) in sy samelewingsfilosofie begin by die soewereiniteit van God oor alles wat Hy geskep het. Aardse soewereiniteit (gesag) is afhanklik van en vloei voort uit dié van God. God gee aan elke verband 'n eie, maar beperkte, soewereiniteit (vgl. Spykman, 1976:185).

Athusius vorder verder as Calvyn deur die twee-rykeleer van staat en kerk te verwerp, asook die idee dat die ander menslike verbande slegs onderdele van die twee sou wees. Volgens hom moet duidelik onderskei word tussen die staat, natuurlike verbande soos die huwelik en gesin, en allerlei kollegiale verenigings. Elkeen van hierdie samelewingsverbande het 'n eie roeping en gesag en mag nie in mekaar se interne sake inmeng nie.

Hy bestry daarom die gangbare idee van sy tyd oor politieke soewereiniteit, byvoorbeeld die goddelike gesag van monargieë, en leer dat politieke soewereiniteit afhanklik is van God se orde, dit beperk is en verantwoording vereis, en dit die volle eie reg van ander verbande moet erken.

Dit is duidelik dat Athusius heelwat verder as sy voorganger, Calvyn, gevorder het:

Athusius has been credited with providing the systematic climax of the reformational social thought of the sixteenth century, and with formulating the first statement of the complementary principle that in later Calvinist tradition came to be known as sphere sovereignity and sphere universality. (McCarthy et al., 1981:46.) 


\subsection{F.J. Stahl (1802-1855)}

Ook die latere Lutherse denker, Stahl, se vertrekpunt is die soewereiniteit van God oor alles, insluitende die menslike samelewing. In sy hoofwerk, Die Philosophie des Rechts nach geschichtlicher Ansicht (1830-1837), beklemtoon hy verder die reg van die verskillende lewensfere teenoor die destyds gangbare gedagte van volksoewereiniteit. Volgens hom ontleen die staat sy gesag en mag nie aan die wil van die volk nie, maar aan God. Kritiek op sy standpunt (vgl. Dengerink, 1948:266) is dat hy normatiewe betekenis aan die historiese ontwikkeling van die samelewing heg. Stahl is egter belangrik ook as gevolg van sy invloed op Groen van Prinsterer.

\subsection{G. Groen van Prinsterer (1801-1876)}

Hierdie denker se visie word in detail behandel deur onder andere Van Dyke (1989) en Dengerink (1948:69-94, 266-267), terwyl Skillen en McCarthy (1991:53-78) die belangrikste Engelse uittreksels uit sy hoofwerk Ongeloof en revolutie (1847) bied. (Van Dyke, 1989:293 e.v. bevat 'n volledige Engelse vertaling van hierdie werk.) Groen van Prinsterer is ook die eerste persoon wat die term "soewereiniteit in eie kring" gebruik. Hy pas dit egter nog hoofsaaklik toe op die verhouding tussen kerk en staat (vgl. Dengerink, 1948:266 en Skillen \& McCarthy, 1991:368).

Hy is sterk deur Stahl beïnvloed en sy denke gaan gevolglik ook mank aan die feit dat hy neig om samelewingsvorme wat in die geskiedenis tot stand gekom het as normatief te beskou. Sy visie op soewereiniteit in eie kring word verder verswak deur sy groot klem op die (Nederlandse) volk (nasionalisme).

\subsection{Abraham Kuyper (1837-1920) en Herman Bavinck (1854- 1921)}

Kuyper se hoofgedagtes oor sy samelewingsvisie is veral vervat in sy Antirevolutionaire Program (1873) en Souvereiniteit in eigen kring (1880) (vgl. Skillen \& McCarthy, 1991:235-298 vir Engelse vertalings). Veenhof (1939) en Dengerink (1948:131-161) bied 'n breedvoerige uiteensetting van sy visie, terwyl waardevolle korter weergawes in Spykman (1976:182-185), Skillen en McCarthy (1991:235242) en McCarthy et al. (1981:46-49) te vinde is.

Kuyper stel sy eie visie teenoor die individualistiese en kollektivistiese strominge van sy tyd. Hierdie strominge lei tot totalitêre politieke stelsels, wat die ander verbande oorheers. Volgens Kuyper 
vervang hulle God se soewereiniteit met eie, menslike soewereiniteit en daarom kan hulle ook nie vryheid waarborg nie.

Kuyper se eie oplossing word kernagtig soos volg deur McCarthy et al. $(1981: 48,49)$ saamgevat:

God's creating Word is the law for ordering our life relationships in all spheres of human endeavor. Each sphere has its own, unique, inviolable, delegated authority. No sphere - not even the two great social institutions that tend to make imperialistic claims, the church and the state - may suppress or tyrannize or draw parasitically upon others. Each should be as a partner with all the others. In a just society there is no room for hierarchies of power and authority. Within each coordinate sphere man must exercise his divinely given office and calling, and men together must honor the rightful roles of each sphere in community life ...

Kuyper was nie net 'n kampvegter vir strukturele pluralisme nie. Sy stryd vir lewensbeskoulik-georiënteerde onderwys en die vryheid van ouers om volgens eie geloofsoortuiging gepaste skole vir hulle kinders te kies toon aan dat hy ook konfessionele pluralisme voorgestaan het. Nogtans toon Dengerink (1948:268) twee lyne by Kuyper aan. Die een is die reformatoriese en die ander die ou dualisme van natuur en genade, wat duidelik in sy leer oor algemene en besondere genade na vore kom. Gelukkig het sy navolgers op die eerste lyn voortgebou.

Ten spyte hiervan mag Kuyper se invloed nie onderskat word nie. Nog steeds vind sy samelewingsbeskouing navolging in verskillende wêrelddele. Die lywige studie van Bolt (2001), maak byvoorbeeld Kuyper se "public theology" op die huidige Amerikaanse samelewing van toepassing en Van der Walt (1999a en 1999b), beskou Kuyper ook as relevant vir Afrika.

Die volgende woorde van Son (1999:181) sou deur baie reformatoriese Christene oor die wêreld met instemming gelees kan word:

The principle of sphere sovereignity is undoubtedly the most creative idea which Abraham Kuyper has contributed to Christians all over the world in their critical analysis of the existing situations and the creative formulation of their future projects. It is, at the same time, sufficiently practical that it could be implemented directly in concrete politics. Also it has turned out to be applicable for the pluralistic society of today. 
Aangesien daar nie veel verskil is in die samelewingsvisies van Kuyper en sy tydgenoot, Bavinck nie, word laasgenoemde se standpunt nie hier behandel nie. (Vir besonderhede, vgl. Spykman, 1976:179-182.)

\subsection{H. Dooyeweerd (1894-1977) en D.H. Th. Vollenhoven (1892-1978)}

Hierdie twee grondleggers van 'n reformatoriese filosofie ontwikkel Kuyper en sy voorgangers se samelewingsfilosofie nog verder (vgl. Dooyeweerd, 1957:157-626; 1962 en 1986). Vollenhoven sit sy samelewingsfilosofie baie kortliks uiteen in Vollenhoven (2005 en 1992). Gepopulariseerde weergawes van hulle beskouings oor die samelewing is te vinde in werke soos dié van Hommes (1982), Kalsbeek (1970 en 1975), Spier (1966) en Spykman (1976:171172).

Hierdie twee denkers se basiese vertrekpunte, byvoorbeeld oor God se soewereiniteit wat deur sy skeppingsordeninge vir die samelewing geld, is dieselfde as dié van hulle voorgangers. Hulle verskil egter van Kuyper, wat die beginsel van soewereiniteit in eie kring net in sosiologiese sin gebruik het. Met behulp van hulle leer van die modaliteite van die werklikheid word soewereiniteit in eie kring nou 'n breër kosmologiese beginsel wat nie net op die menslike samelewing van toepassing is nie.

Hierdie leer van die aspekte, funksies of modaliteite stel die twee Christelike filosowe in staat om nog fyner tussen verskillende samelewingsverbande en hulle onderlinge verhoudings te onderskei. Elke verband het sowel 'n funderende/begrondende as 'n leidende/ bestemmingsfunksie. Ingewikkelde enkaptiese vervlegting in en tussen verbande word ook aangetoon. Op hierdie wyse word die reformatoriese samelewingsfilosofie nog 'n stap verder uitgebou.

Met die werk van Vollenhoven en Dooyeweerd is hierdie samelewingsfilosofie feitlik sistematies afgerond. Hulle navolgers beperk hulle hoofsaaklik tot die toepassing daarvan op verskillende terreine, asook tot kritiese vrae oor sekere aspekte daarvan.

\subsection{Terugblik}

Uit hierdie kort historiese oorsig word twee dinge duidelik. Hoewel dit lank geneem het om tot sy huidige vorm te ontwikkel, blyk dat die reformatoriese samelewingsbeskouing nie 'n statiese dogma was of is nie. Dit het deur die eeue dinamies ontwikkel en steeds 'n ryker 
inhoud verkry. Aan die een kant het dit 'n boodskap vir elke tyd gehad en is dit nog steeds relevant ook vir die pluralistiese en globaliserende kontemporêre wêreld van vandag (vgl. byvoorbeeld Son, 1999:184-189).

Aan die ander kant bemerk 'n mens, veral as gevolg van die Bybelse begronding van hierdie samelewingsvisie, 'n merkwaardige kontinuïteit in die gedagtegang van die verskillende verteenwoordigers wat bespreek is. Sekere basiese vertrekpunte word konstant gehandhaaf en loop deur die lang geskiedenis. Die gedagte van God se soewereiniteit, wat byvoorbeeld by Calvyn begin, loop deur tot vandag (vgl. byvoorbeeld die titel van Taljaard, 1976). Ook die gedagte dat God die samelewing deur verskillende skeppingsordeninge regeer, wat 'n verskeidenheid samelewingsvorme ('n pluralistiese samelewing) tot gevolg het, loop deur die geskiedenis.

\section{Samevattende gevolgtrekking}

Die vraagstuk waarmee hierdie artikel begin het, was dat baie Christene met geen of met 'n baie onduidelike of dalk selfs met 'n Bybelsvreemde samelewingsbeskouing die sosiale vraagstukke van hulle tyd benader. Die voorafgaande verkenning het aangetoon dat dit nie so hoef te wees nie: 'n reformatoriese samelewingsfilosofie is beskikbaar, hoe onvolmaak ook al.

Hierdie artikel kan dus op gepaste wyse afgesluit word met die volgende waardering van so 'n Skrifgefundeerde samelewingsvisie:

An original idea with the solid support of Scripture is difficult to produce, and it is still more difficult to have one that can be applied fruitfully to concrete situations. The principle of sphere sovereignity, though not entirely free from weaknesses, is one of the most important treasures bestowed upon the Reformed communities of the world today. It is consistent with the characteristic teachings of Calvinism and, at the same time, very pertinent to the spherical pluralism of today. We should be grateful to God for it (Son, 1999:189).

\section{Geraadpleegde bronne}

ADEYEMO, T., ed. 1993. A Christian mind in a changing Africa. Nairobi: Association of Evangelicals in Africa.

ALTHUSIUS, J. 1964. Politics. Translated by F.S. Carney. London: Eyre \& Spottiswoode.

BOLT, J. 2001. A free church, a holy nation: Abraham Kuyper's American public theology. Grand Rapids: Eerdmans.

CAMPBELL, T. 1987. Seven theories of human society. Oxford: Clarendon. 
CHAPLIN, J. 1994. Subsidiarity as a political norm. (In Chaplin, J. \& Marshall, P., eds. Political theory and Christian vision. Lanham: University Press of America. p. 81-100.)

DENGERINK, J.D. 1948. Critisch-historisch onderzoek naar de sociologische ontwikkeling van het beginsel der "souvereiniteit in eigen kring" in de 19e en 20e eeuw. Kampen: Kok.

DENGERINK, J.D. 1961. Soevereiniteit in eigen kring. (In Grosheide, F.W. \& Van Itterzon, G.P., reds. Christelijke Encyclopedie. Vol. 6. Kampen: Kok. p. 211-212.)

DOOYEWEERD, H. 1957. A new critique of theoretical thought. Vol. 3. Amsterdam: Presbyterian \& Reformed Publishing.

DOOYEWEERD, H. 1962. Verkenningen in de Wijsbegeerte, de Sociologie en de Rechtswetenschap. Amsterdam: Buijten \& Schipperheijn.

DOOYEWEERD, H. 1986. A Christian theory of social institutions. La Jolla: Herman Dooyeweerd Foundation.

FOWLER, S. 1985. Biblical studies in the gospel and society. Potchefstroom: Institute for Reformational Studies.

HOMMES, H. VAN E. 1982. Inleiding in de wijsbegeerte van Herman Dooyeweerd. 's-Gravenhage: Nijhoff.

KALSBEEK, L. 1970. De wijsbegeerte der wetsidee: proeve van een Christelijke filosofie. Amsterdam: Buijten \& Schipperheijn.

KALSBEEK, L. 1975. Contours of a Christian philosophy; an introduction to Herman Dooyeweerd's thought. Toronto : Wedge Publishing Foundation.

KLAPWIJK, 1995. Op zoek naar de mensbeeld van liberalisme, socialisme en Christen-democratie. (In Van Woudenberg, R. \& Griffioen, S., reds. Jacob Klapwijk: transformationele filosofie: cultuur-politieke ideeën en de kracht van een inspiratie. Kampen: Kok. p. 134-151.)

KUYPER, A. 1998. Sphere sovereignty. (In Bratt, J.D., ed. Abraham Kuyper: a centennial reader. Grand Rapids: Eerdmans. p. 461-490.)

MCCARTHY, R., OPPEWAL, D., PETERSEN, W., SPYKMAN, G., eds. 1981. Society, state and schools: a case for structural and confessional pluralism. Grand Rapids: Eerdmans.

NIEBUHR, R. 1951. Christ and culture. New York: Harper.

SADOWSKY, J.A. 1986. Classical social doctrine in the Roman Catholic Church. (In Block, W. \& Hexam, I., eds. Religion, economics and social thought. Vancouver: Fraser Institute. p. 3-46.)

SKILLEN, J.W. \& MCCARTHY, R.M., eds. 1991. Political order and the plural structure of society. Atlanta: Scholars Press.

SON, B.H. 1999. Relevance of sphere sovereignty to Korean society. (In Van der Kooi, C. \& De Bruijn, J., eds. Kuyper reconsidered: aspects of his life and work. Amsterdam: V.U.-Uitgeverij. p. 179-189.)

SPIER, J.M. 1966. An introduction to Christian philosophy. Nutley: Craig.

SPYKMAN, G.J. 1976. Sphere-sovereignity in Calvin and the Calvinist tradition. (In Holwerda, D.E., ed. Exploring the heritage of John Calvin. Grand Rapids: Baker. p. 163-208.)

SPYKMAN, G., COOK., G., DODSON, M., GRAHN, L., ROOY, S. \& STAM, J. 1988. Let my people live: faith and struggle in Central America. Grand Rapids: Eerdmans.

STEVENSON, L. 1974. Seven theories of human nature. Oxford: Oxford University Press. 
TALJAARD, J.A.L. 1976. Polished lenses: a philosophy that proclaims the sovereignty of God over creation and also over every aspect of human activity. Potchefstroom: Pro Rege.

VAN DEN BRINK, G., GEERTSEMA, H.G. \& HOOGLAND, J. 1997. Filosofie en theologie: een gesprek tussen Christen-filosofen en -theologen. Amsterdam: Buijten \& Schipperheijn.

VAN DER WALT, B.J. 1999a. Religion and society: Christian involvement in the public square. Potchefstroom: Institute for Reformational Studies.

VAN DER WALT, B.J. 1999b. Christian religion and society: the heritage of A. Kuyper for (South) Africa. (In Van der Kooi, C. \& De Bruuijn, J., eds. Kuyper reconsidered: aspects of his life and work. Amsterdam: V.U.Uitgeverij. p. 228-237.)

VAN DER WALT, B.J. 2002. The liberating message: a Christian worldview for Africa. Potchefstroom: The Institute for Contemporary Christianity in Africa.

VAN DYKE, H. 1989. Groen van Prinsterer's lectures on unbelief and revolution. Jordan Station: Wedge Publishing Foundation.

VEENHOF, C. 1939. Souvereiniteit in eigen kring: schets van de leer der "souvereiniteit in eigen kring" zooals die door dr. A. Kuyper werd ontwikkeld. Kampen: Kok.

VOLLENHOVEN, D.H. Th. 1992. De soevereiniteit in eigen kring by Kuyper en ons. (In Tol, A. \& Bril, K.A., reds. Vollenhoven als wijsgeer: inleidingen en teksten. Amsterdam: Buijten \& Schipperheijn. p. 36-46.)

VOLLENHOVEN, D.H. Th. 2005. Introduction to philosophy. Ed. by J.H. Kok \& A. Tol. Sioux: Dordt College Press.

WOLTERS, A.M. 1990. Christianity and the classics: a typology. (In Helleman, W.E., ed. Christianity and the classics. Lanham: University Press of America. p. 189-203.)

WOLTERS, A.M. 1991. Gustavo Guittiérez (1928- ). (In Klapwijk, J., Griffioen, S. \& Groenewoud, G., eds. Bringing into captivity every thought: capita selecta in the history of Christian evaluations of non-Christian philosophy. Lanham: University Press of America. p. 229-240.)

WOLTERSTORFF, N. 1983. Until justice and peace embrace: the Kuyper lectures for 1981 delivered at the Free University of Amsterdam. Grand Rapids: Eerdmans.

\section{Kernbegrippe:}

kerk en samelewing

reformatoriese tradisie

samelewingsfilosofie

soewereiniteit in eie kring

sosiale pluralisme

\section{Key concepts:}

church and society

reformational tradition

social philosophy

social pluralism

sphere sovereignity 
